\title{
Using nurses for preventive activities with computer assisted follow up: a randomised controlled trial
}

\author{
J Robson, K Boomla, S Fitzpatrick, A J Jewell, J Taylor, J Self, M Colyer
}

\begin{abstract}
Objective-To assess whether an organised programme of prevention including the use of a health promotion nurse noticeably improved recording and follow up of cardiovascular risk factors and cervical smears in a general practice that had access to computerised call and recall.
\end{abstract}

Design-Randomised controlled trial.

Setting-General practice in inner London.

Patients-All 3206 men and women aged 30-64 registered with the practice.

Intervention-The intervention group had their risk factors ascertained and followed up by the health promotion nurse and the general practitioner, whereas those in the control group were managed by the general practitioner alone.

End point-Recording and follow up of blood pressure and cervical smears after three years. Recording of smoking, family history of ischaemic heart disease, and serum cholesterol concentrations were also examined.

Measurements and main results - When the trial was stopped after two years the measurements of blood pressure in the preceding five years were 93\% (1511/1620) v 73\% (1160/1586) (95\% confidence interval for difference 17.5 to $22 \cdot 7 \%$ ) for intervention and control groups respectively. For patients with hypertension the figures were $97 \%(104 / 107) v 69 \%$ $(80 / 116)(18.2$ to $38 \cdot 2 \%)$. For women the proportion who had had a cervical smear in the preceding three years were $76 \%(606 / 799) v 49 \%(392 / 806)(22.5$ to $31 \cdot 9 \%$ ). Recording of smoking, family history of ischaemic heart disease, and serum cholesterol concentrations was also higher in the intervention group compared with the control group.

Conclusion-An organised programme, which includes a nurse with specific responsibility for adult prevention, is likely to make an important contribution to recording of risk factors and follow up of those patients with known risks.

\section{Introduction}

Preventing cardiovascular disease, diseases related to smoking, and cervical cancer is a priority for primary care services. ${ }^{12}$ National strategies exist for child and maternity services supported by health visitors and midwives. ${ }^{3+}$ No professional group has specific responsibility for preventive health or anticipatory care for adults, though most agree that such activities are appropriately based in primary care. Doubts both about the efficacy and feasibility of preventive action for whole populations and about government commitment to necessary resources remain. ${ }^{56}$ The need for adequately organised services can be set against the increasing gap between the expectation for prevention and the delivery of care.
Though the failure to apply what is known to be effective is at its most acute in industrial areas and inner cities, delivering preventive care is a national problem. ${ }^{8}$ No single professional group can bridge this gap; the magnitude of the task requires coherent team approaches backed up by clerical staff and information systems capable of collating multiple risks in entire populations.

The underused potential of nurses has been recognised ever since the Burlington trial showed that for specified tasks nurses performed at least as well as doctors. ${ }^{910}$ When successful preventive programmes have been organised, trained nurses have played a key role either as nurses employed by practices or, as in Glasgow, as health visitors employed by the district. ${ }^{11 \cdot 13}$ In Tower Hamlets (east London) fewer than $10 \%$ of practices have employed nurses, and in inner London as a whole the figure is still only $25 \%$. $^{14}$ Morrell et al have shown the deleterious effects of restricted time in consultations on preventive activities, ${ }^{15}$ and additional staff time and changes in the content of consultations seem to be necessary for prevention.

Several studies have shown the benefits of organised preventive programmes, ${ }^{16-20}$ though the contribution of nurses has not been specifically examined. We assessed the process of care by measuring the recording of preventive activities when the doctor worked alone compared with recording achieved when the doctor and nurse worked together. Such a programme would have effects on the group allocated to normal care as well as the intervention group. The contribution of the health promotion nurse was, however, felt to be sufficiently distinct and the numbers of patients high enough to have a $95 \%$ chance of detecting a $10 \%$ difference in recording significance at $p<0 \cdot 05$. The primary end points were recording of blood pressure and cervical smears after three years. Recording of smoking, family history of ischaemic heart disease, and serum cholesterol concentrations was also documented.

\section{Methods}

In 1984 a group practice of five doctors in east London with 9000 registered patients employed a health promotion nurse, whose primary task was the preventive care of adults. After three months' training she transferred records of cardiovascular risk factors and cervical smears on all patients aged 30-64 from the manual record to a modified relational database (Dataflex) running on a multiuser 16 bit computer (Equinox). She was helped by a clerk, and the time for transfer was equivalent to one person working for nine months. Validation procedures identified errors in transcription, and the registration was checked with the family practitioner committee and by postal 
inquiry or personal visit to patients' homes. ${ }^{21}$ All patients aged 30-64 registered with the practice and known by postal or personal inquiry to live at their stated address were included and randomly allocated (with random number tables) to control or intervention groups identified by marking the notes. New patients aged 30 and over and existing patients reaching the age of 30 during the trial were included. Patients reaching 65 years and those patients who left the practice during the trial were excluded.

The general practitioners were taught to use the computer and encouraged to make full use of its facilities for follow up. They were asked to manage and follow up their patients in whatever way they thought best. In a series of preparatory meetings protocols for preventive activity and follow up to be used by the health promotion nurse were agreed by all participants. Regular meetings continued to review and support the programme. Each doctor and the nurse had a computer terminal in his or her consulting room on which each agreed to enter blood pressure, history of smoking, and records of cervical smears. Recording of the following was encouraged: history of ischaemic heart disease in the patient and his or her first degree relatives under the age of 65 , serum cholesterol concentrations when appropriate, and dietary and antismoking advice. The age-sex register was maintained by reception staff with a terminal at the reception desk. ${ }^{22}$

For blood pressure the computer automatically entered a date for follow up based on a "box system" of graded risk. ${ }^{23}$ Blood pressures for box allocation were based on age specific mortality taken from American actuarial data. ${ }^{24}$ Box 0 contained patients who had never had their blood pressure recorded. Box 1 contained those at low risk with a five year recall. Box 2 contained those with moderate risk and yearly recall. Box 3 was a transitional box, which, if sustained over a mean of three readings, allocated the patient to box 4-patients with hypertension requiring treatment with three monthly follow up. Hypertensive patients already receiving treatment were allocated to box 4 . This was a dynamic system in which a single reading (systolic or diastolic, whichever was higher) determined initial and upward allocation, and movement downwards was based on the mean of preceding readings. Allocation to box 4 was permanent. Recall dates for cervical smears were three yearly unless abnormalities dictated otherwise. Facilities existed to identify women who had had hysterectomies or those who declined to take part in the programme.

Patients had open access to the health promotion nurse, who also saw newly registering patients. Most patients, however, saw her after routine consultations with the general practitioner. In addition, the nurse ran monthly computer searches, which identified patients without any record of risk factors or those requiring recall. These patients were contacted and asked to arrange to see the nurse. Recall was based on allocation to a particular box depending on blood pressure or the date for another cervical smear. The scheme thus used routine attendances to the surgery combined with systematic recall for follow up or nonattendance. ${ }^{25}$ Validation of the register was maintained by postal inquiry, checks with the family practitioner committee, and domiciliary visits to non-respondents. A survey at two years showed that list inflation in the study population was $8 \cdot 8 \%$ with no significant difference between control and intervention groups. Although the trial had been designed to last three years, it was stopped after two years because participating doctors were not prepared to continue excluding half the practice from access to the health promotion nurse.

The normal approximation to the binomial distribu- tion for proportions was used to calculate confidence intervals and to test for significance.

\section{Results}

At the start of the study in 1986 there was no significant difference in recording preventive activities between control and intervention groups. Over the next two years the intervention group had a higher rate of increase in recording than that in the control group. Figs 1 and 2 illustrate these trends (with 95\% confidence intervals). Averaged over all preventive activities data for the intervention group showed a $34 \%$ increase and the control group a $10 \%$ increase in recording after two years.

The table shows the results at the end of the study in 1988. The proportion of patients who had had their blood pressure recorded within the preceding five

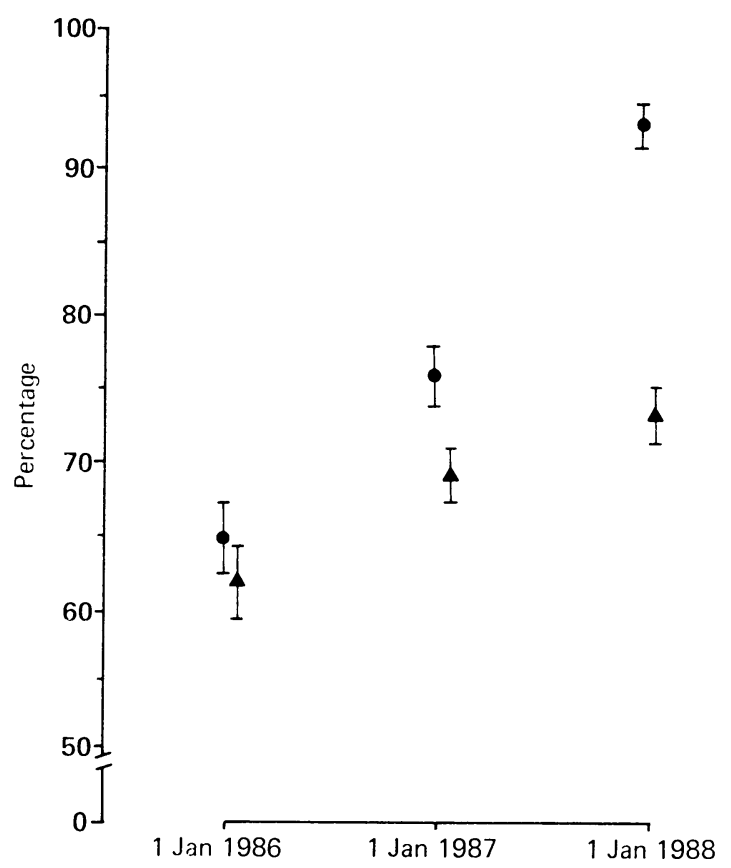

FIG 1-Proportion of patients with blood pressure recorded within preceding five years, 1986-8. Nurse and doctor $(1986-n=1550$; $1987-n=1669 ; 1988-n=1620) . \quad \Delta$ Doctor $(1986-n=1567$ $1987-n=1617 ; 1988-n=1586$

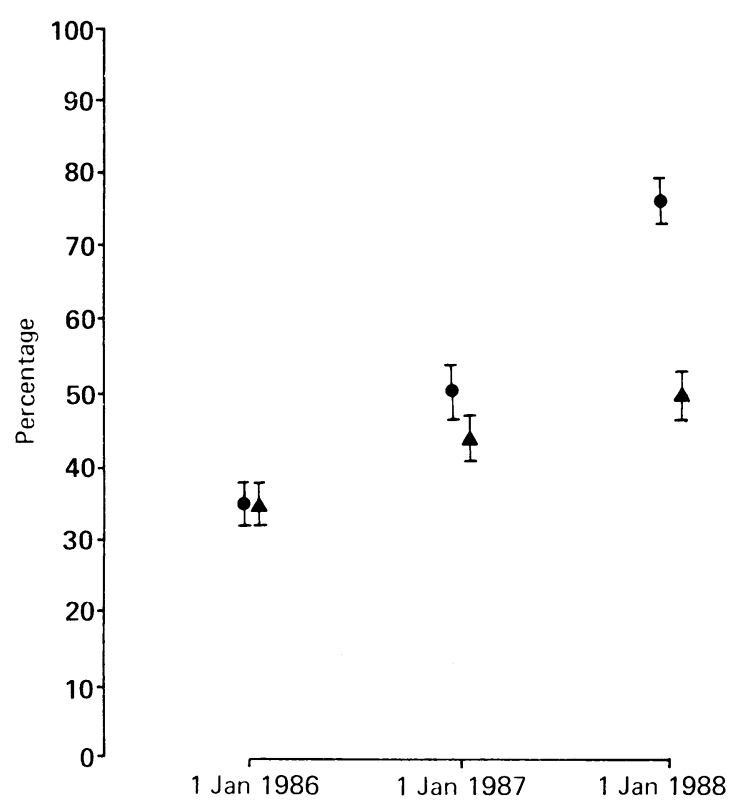

FIG 2-Proportion of women with cervical smear performed within preceding three years, 1986-8. Nurse and doctor $(1986-n=771$, $1987-n=828 ; 1988-n=799)$. \ Doctor $(1986-n=802 ; 1987-$ $n=826 ; 1988-n=806$ ) 


\begin{tabular}{|c|c|c|}
\hline Preventive activity & $\begin{array}{l}\text { Intervention } \\
\text { group (nurse } \\
\text { and doctor) }\end{array}$ & $\begin{array}{l}\text { Control group } \\
\text { (doctor) }\end{array}$ \\
\hline Blood pressure recorded within preceding five years & $1511 / 1620(93)$ & $1160 / 1586(73)$ \\
\hline $\begin{array}{l}\text { Hypertensive patients (boxes } 3 \text { and 4) with blood pressure record within } \\
\text { preceding year }\end{array}$ & $104 / 107(97)$ & $80 / 116(69)$ \\
\hline Patients with record within preceding five years of whether or not they smoked & $1180 / 1620(73)$ & $907 / 1586(57)$ \\
\hline $\begin{array}{l}\text { Patients with record at any time of whether or not there was family } \\
\text { history of heart attack }\end{array}$ & $838 / 1620(52)$ & $388 / 1586(24)$ \\
\hline $\begin{array}{l}\text { Patients with positive family history of heart attack who had serum cholesterol } \\
\text { recorded at any time }\end{array}$ & $106 / 264(40)$ & $29 / 104(28)$ \\
\hline $\begin{array}{l}\text { Women with cervical smear recorded within preceding three years (excluding } \\
\text { women with hysterectomy) }\end{array}$ & $606 / 799(76)$ & $392 / 806(49)$ \\
\hline
\end{tabular}

years was $93 \%$ for the intervention group compared with $73 \%$ for the control group, a difference of $20 \%$ (95\% confidence interval $17 \cdot 5$ to $22.7 \%$; $<<0.001$ ). The proportion of patients with hypertension (box 4) or who had had fewer than three readings in the hypertensive range (box 3) but had not had blood pressure recorded within the preceding year was $97 \%$ compared with $69 \%$, a difference of $28 \%$ (18.2 to $38 \cdot 2 \% ; \mathrm{p}<0 \cdot 001)$.

The proportion of patients in whom smoking state had been recorded within the preceding five years was $73 \%$ compared with $57 \%$, a difference of $16 \%(12 \cdot 3$ to $18.9 ; \mathrm{p}<0.001)$. The proportion of patients who had a record at any time of whether there was a family history of heart attack was $52 \%$ compared with $24 \%$, a difference of $28 \%$ ( 23.8 to $30.6 \%$; $<<0.001$ ).

In patients with a family history that was positive for ischaemic heart disease $40 \%$ in the intervention group had had their serum cholesterol concentration recorded compared with $28 \%$ in the control group, a difference of $12 \%(1 \cdot 3$ to $23 \cdot 1 \% ; \mathrm{p}<0 \cdot 05)$. For recording cervical smears in the preceding three years in women who had not had a hysterectomy the proportions were $76 \%$ compared with $49 \%$, a difference of $27 \%(22 \cdot 5$ to $31 \cdot 9 \% ; \mathrm{p}<0 \cdot 001)$.

\section{Discussion}

The $10 \%$ average increase in preventive recording in the control group after two years was modest compared with the $34 \%$ improvement in recording in the intervention group. The $24 \%$ additional improvement can be attributed to the effect of the intervention programme. The aspect that showed the greatest improvement with intervention was follow up. These results suggest that with organisation and resources over $90 \%$ recording and follow up of risk factors in general practice can be achieved even in the most adverse inner city conditions and that nurses with defined responsibilities for adult anticipatory care are a key feature of such schemes.

Though organising manual records was necessary, all participants in the study agreed that the task of surveillance of multiple risks and recall for the entire adult population would be extremely difficult without a computer. The computer was a prerequisite for change, but, as the control group showed, it was not enough to achieve high levels of recording. Attention to the responsibilities and organisation of care were key features contributing to the high levels of delivery achieved in the intervention group. ${ }^{26}$

The skills of the health promotion nurse were an unquantified part of the intervention programme. Patients had open access to the nurse, who, in addition to detecting risks and counselling, dealt with a wide range of medical and psychosocial problems, which were often the starting point for further dialogue and health promotion. ${ }^{27}$

\section{costs}

The computer was funded with grants, and the health promotion nurse had some financial support from the district health authority, with whom she had her contract of employment. A multiuser computer system with printers and tape back up supporting up to eight terminals now costs about $£ 3000$ per principal, with a yearly maintenance contract of $£ 500$ a year. Loading of age-sex registers is now done with computers by family practitioner committees in many regions, and transcription of data and postal or telephone recall can be undertaken by trained clerical staff. These costs are not inconsiderable and may add up to an initial $£ 12000$ for a group practice of four principals, with yearly costs of $£ 2000$. Salaries, postage, and above all the time required for organisation are further additions to the necessary resources required for increased ascertainment.

Although the practice started off from a baseline of recorded preventive activity above average for inner London, ${ }^{28}$ the project was completed against a background of high workload (4.0 total consultations/ patient/year) and overcrowded premises in a poor condition. Rates of consultation with the general practitioners stayed the same during the trial.

\section{FURTHER DEVELOPMENTS}

The need for these resources may prove to be a major obstacle in developing such schemes, especially in inner cities and other areas of high need. ${ }^{29}$ Nevertheless, the scheme has been enthusiastically received in the district. Tower Hamlets has some of the worst social conditions in Britain and primary care services lag 15 years behind the rest of England and Wales. ${ }^{30}$ Despite these obstacles to delivery of care the scheme has proved sufficiently robust to expand. There are currently six health promotion nurses based in six group practices covering a quarter of the district's adult population, and there are plans for further expansion. Protocols for prevention have been developed through consensus with general practitioners, health promotion nurses, and district representatives. They represent the emergence of a practical and coherent prevention strategy among adults in the borough based on primary care. Regular meetings include all participants and provide continuing support, education, and audit. Funding of computerisation has proved elusive and manual systems are maintained at present.

The computer system was funded by the Greater London Council and the King Edward's Hospital Fund for London. The scheme was greatly helped by Mr A Bennett, administrator, City and East London Family Practitioner Committee; Dr J Richards, district medical officer; $\mathrm{Mr} J$ Rowson, director of computing, The London Hospital, El; Mr C Megan, City Technology Centre, who wrote the software; and Ms M Ridley. Mr S Evans, Dr J Tudor Hart, Dr D Irvine, and Professor D C Morrell commented on the paper.

1 ... yal College of General Practitioners. Prevention of arterial disease in general practice. London: RCGP, 1981. (Report from general practice 19. )

2 Department of Health and Social Security. Cervical cancer screening. London DHSS, 1988. (Health Circular (88)1.)

3 Committee on Child Health Services. Fit for the future. Vols 1 and 2. London: HMSO, 1976. (Cmnd 6684.)

4 Social Services Committee. Perinatal and neonatal mortality. Vol 1. London: HMSO, 1980.

5 Lichtenstein MJ, Elwood PC, Thomas MF, Sweetnam PM. Doctors opinion on the prevention of myocardial infarction. $\mathcal{F} R$ Coll Gen Pract 1985;35: $516-9$.

6 National Forum for Coronary Heart Disease Prevention. Coronary heart disease prevention; action in the UK 1984-1987. London: Health Education Authority, 1988 .

7 Robson J. Bridging the expectation delivery gap. In: Pereira Gray DJ, ed. The medical annual Bristol: W'right, 1986.

8 Hart JT. Measurement of omission. Br Med f 1982;284:1686-9.

9 Hart JT. Practice nurses: an underused resource. Br Med f 1985;290:1162-3.

10 Spitzer WO, Sackett DL, Sibley JC, et al. The Burlington randomized trial of the nurse practitioner. $N$ Engl 7 Med 1974:290:251-6.

11 Stilwell B, Greenfield S, Drury M, Hull FM. A nurse practitioner in general practice: working style and pattern of consultations. $\mathcal{F} R$ Coll Gen Pract practice: working

12 Fullard E, Fowler G, Gray M. Facilitating prevention in primary care. BrMed f 1984;289:1585-7.

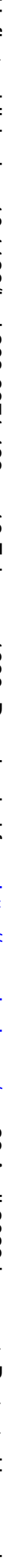


13 Greater Glasgow Health Board. Good hearted Glasgow; the first year. Glasgow: Greater Glasgow Health Board, 1987.

14 Jarman B. A survey of primary care in London. London: Royal College of General Practitioners, 1981. (Occasional paper 16.)

15 Morrell DC, Evans ME, Morris RW, Roland M. The "five minute" consultaion: effect of time constraint on clinical content and patient satisfaction. Br Med f 1986;292:870-3.

16 Kenkre J, Drury VWM, Lancashire RJ. Nurse management of hypertensio clinics in general practice assisted by a computer. Fam Pract 1985;2:17-22.

17 Fullard E, Fowler G, Gray M. Promoting prevention in primary car controlled trial of low technology, low cost approach. Br Med F 1987;294 1080-1.

18 McAlister NH, Covvey DH, Tong C, Lee A, Wigle DE. Randomised controlled trial of computer assisted management of hypertension in primary care. Br Med f 1986;293:670-4.

19 Difford F, Telling JP, Davies KR, Fornear JE, Reading CA. Continuous opportunistic and systematic screening for hypertension with computer help: analysis of non-responders. BrMed f 1987;294:1129-32.

20 Brownbridge G, Evans A, Fitter $M$, Platts $M$. An interactive computerized protocol for the management of hypertension: effects on the general protocol for the management of hypertension: effects on the

21 Fraser RC, Clayton DG. The accuracy of age-sex registers, practice medical records and family practitioner committee registers. $f R$ Coll Gen Pract $1981 ;: 410-9$

22 Chrisp Street Practice. Developing a computerised preventive programme. The Practitioner 1987;231:1634-9.

23 Coope J. Hypertension. Br Med f 1982;284:1449-50.

24 Whelton PK. Blood pressure in adults and the elderly. In: Bulpitt CJ, ed. Epidemiology of hypertension. Amsterdam: Elsevier, 1985.

25 Pill R, French J, Harding K, Stott N. Invitation to attend a health check in general practice setting: comparison of attenders and non-attenders. $\mathcal{F} R$
Coll Gen Pract 1988;38:53-6.

26 Department of Health and Social Security. A prescription for change. A report on the longer term use of and development of computers in general practice. London: HMSO, 1986.

27 Pill R, Stott N. Invitation to attend a health check in a general practice setting: the views of a cohort of non-attenders. $\mathcal{F} R$ Coll Gen Pract 1988;38:57-60.

28 Michael G. Quality of care in managing hypertension by case finding in north west London. Br Med f 1984;288:906-8.

29 Butler JR. Primary care in the inner cities. Br Med f 1986;293:1519-20.

30 Hull S, Livingstone A, Dunford A. The general practitioner in the inner city.

$\exists R$ Coll Gen Pract 1984;34:469.

(Accepted 9 fanuary 1989)

BOOKS RECEIVED

\section{Biology}

Advances in Membrane Fluidity. Vol 2. "Lipid Domains and the Relationship to Membrane Function." Ed R C to Membrane Function." Ed R C Series editor R C Aloia. ( $P p x+301$; Series editor R C Aloia. (Pp x+301;
$\$ 120$.) New York: Liss, 1988. Distributed by John Wiley and Sons. ISBN buted by John

$0-8451-4601-7$.
Advances in Membrane Fluidity. Vol 3. "Physiological Regulation of Membrane Fluidity." Ed R C Aloia. C C Curtain, L M Gordon. Series editor R C Aloia. (Pp x +369; figs; \$120.) New York: Liss, 1988. Distributed by John York: Liss, 1988. Distributed by John

\section{Bone}

Contemporary Issues in Endocrinology and Meabolism. Vol 5. "Metabolic Bone and Mineral Disorders." Ed S C Manolagas, J M Olefsky. Series edito J M Olefsky. (Pp xi +254 ; figs; $£ 40$. New York: Churchill Livingstone 1988. ISBN 0-443-08586-2.

\section{Cardiology}

Cardiovascular Clinics. 19/1. "Cardiomyopathies: Clinical Presentation, Differential Diagnosis, and Management." Ed J A Shaver. Series editor A N Brest. (Pp xvii + 288; figs; 449.95 .) Philadelphia: Davis, 1988. ISBN 0-8036-7821-5.

Clinical Electrocardiography: a Treatise for Medical Consultants, Post-graduate Students and Paediatricians. N J Shah, S N Shah. (Pp viii + 231; figs; Rs 225 . Bombay: Samant and Company, 1988 Distributed by Vora Book Centre, 6 Princess Building, Near J J Hospital

Developments in Cardiovascular Medicine. "Catheter Ablation of Medicine. "Catheter Ablation of
Cardiac Arrhythmias: Basic BioCardiac Arrhythmias: Basic Bio-
electrical Effects and Clinical Indicaelectrical Effects and Clinical Indica-
tions." Ed M M Scheinman. (Pp xii tions." Ed M M Scheinman. (Pp xiit
207; figs; £43.25.) Boston: Nijhoff, 207; figs; £43.25. Boston: Nijhoff,
1988. Distributed by MTP Press. ISBN 0-89838-967-4.

Developments in Cardiovascular Medicine. "Oxygen Radicals in the Pathophysiology of Heart Disease." Ed P K Singal. (Pp xii + 348; figs £45.75.) Boston: Kluwer, 1988. ISBN 0-89838-375-7.

Essentials of Cardiologv. A D Timms. Pp xi+272; figs; $£ 10.95$ paperback. Oxford: Blackwell Scientific, 1988 ISBN 0-632-02053-9.

New Perspectives in Cardiac Pacing. Ed S S Barold, J Mugica. (Pp xiii +441 figs; $\$ 60$.) New York: Futura, 1988 ISBN 0-87993-330-5.

Rheumatic Diseases and the Heart. J A Cosh, J V Lever. (Pp xiv +250 ; figs £49.50.) London: Springer, 1988 ISBN 3-540-19524-6.

\section{Cardiovascular diseases}

Coronary Heart Disease: Risks and Reasons. A G Shaper. Pp 70; figs; paperback, price not stated.) London: Current Medical Literature, 1988 ISBN 1-85009-007-6.

\section{Communicable diseases}

Contemporary Issues in Infectiou Diseases. Vol 7. "Parasitic Infections." Ed J H Leech, M A Sande, R K Root. Series editors $M$ A Sande, R K Root. Pp xii $364 ;\{42.50$.) New York: Churchill Livingstone, 1988. ISBN 0- 443-08561-7.

\section{Community medicin}

Health Visitors and Groups: Politic and Practice. Ed V Drennan. (Pp ix + and Practice. Ed Drennan. (Pp ixt Heinemann Nursing, 1988. ISBN 0-433-00033-3.

\section{Dermatology}

Dermatological Signs of Internal Diseas J P Callen, J Jorizzo, K E Greer, et al. Pp $\mathrm{x}+383$; figs and colour plates £34.50. Philadelphia: Saunders, 1988. Distributed by Harcourt, Brace, Jovanovich. ISBN 0-7216-1860-X.

Supplement to the Fourth Printing of Histologic Diagnosis of Inflammatory Skin Diseases. A Method of Pattern Analysis. A B Ackerman. (Pp 48; figs; price not stated.) Philadelphia: Lea and Febiger, 1988. ISBN 0-8121 1158-3.

World Health Organisation Technical Report Series 768. "WHO Expert Committee on Leprosy," Sixth Repor. World Health Organisation. $\mathrm{Pp} 51$; Sw frs 8 paperback.) Geneva: World Health Organisation, 1988. ISBN 92 4-120768-X.

\section{Diabetes}

The Experience of Illness. "Diabetes." $D$ Kelleher. Series editors R Fitzpatrick, S Newman. (Pp vii 99; 88.95 paperback.) London: Routledge, 1988. ISBN 0.415 00726-7.

\section{Ear, nose, and throat}

Oral Pathology. I van der Waal, W A $M$ van der Kwast. (Pp 392; figs an colour plates; $\{70.50$.) Chicago: Quintessence Publishing, 1988. ISBN 0-86715-197-8.

\section{Endocrinology}

Advances in Metabolic Disorders. Vol 11. "Gastrointestinal Hormones." Ed V Mutt. Series editors $R$ Luft, $R$ Levine. (Pp x+545; figs; \$110.) San Diego: Academic Press, 1988. ISBN 0-12-027311-X.

Endocrinology: People and Ideas. Ed S M McCann. (Pp x+471; figs; £58. Oxford: Oxford University Press, 988, for the American Physiologic Society. ISBN 0-19-520718-1.

Melatonin: Clinical Perspectives. Ed A Miles, D R S Philbrick, C Thompson.
(Pp xi +288 ; figs; £40.) Oxford: Oxford University Press, 1988. ISBN 0-19 261652-8.

\section{Environmental and public health}

Environmental Health. No 31. "Guidelines for Healthy Housing." World Health Organisation. ( $\mathrm{Pp}$ xiii +244 ; paperback, price not stated.) Copenhagen: World Health Organisation Regional Office for Europe, 1988.

\section{Gastroenterology}

BMA Family Doctor Guides. "Gallstones and Liver Problems." $M$ Bateson. Series editor T Smith. ( $\mathrm{Pp}$ 98; figs; £2.99 paperback.) Wellingborough: Equation, in association borough: Equation, in association
with the British Medical Association, with the British Medical A

\section{General medicine}

Contemporary Internal Medicine: Clinical Case Studies. Vol 1. Ed J Bowen, E L Mazzaferri. (Pp xv $+319 ; \$ 45$.) New York: Plenum Medical, 1988. ISBN 0-306-43000-2.

\section{General practice}

Education for Health: a Manual on Health Education in Primary Health Care. World Health Organisation. $(\mathrm{Pp}$ xiii+261; figs; Sw frs 34 paperback.) Geneva: World Health Organisation, 1988. ISBN 92-4-154225-X.

Learning General Practice: a Structured Approach for Trainee GPs and Trainers. A Sandars, R Baron. ( $\mathrm{Pp} \mathrm{x}+118 ; £ 9.50$ J Sandars, R Baron. (Pp x+118; $£ 9.50$
paperback.) Hemel Hempstead: Paspaperback.) Hemel Hempstead: Pas41-X.

\section{Genetics}

The Practical Approach Series. "Genome Analysis: a Practical Ap proach." Ed K E Davies. Series editors D Rickwood, B D Hames. (Pp xiv +192 ; figs; £27.) Oxford: IR
Press, 1988. ISBN 1-85221-109-1.

\section{Geriatrics}

BMA Family Doctor Guides. "Confusion in Old Age." J P Wattis. Serie editor T Smith. (Pp 109; figs; $£ 2.99$ paperback.) Wellingborough: Equation, in association with the Britis Medical Association, 1988. ISBN 1-85336-076-7:

\section{Health care issues}

Bath Social Policy Papers. No 12. "Inspecting for Quality: Services for the Elderly." P Day, R Klein, G Tipping. (Pp iii +61 ; paperback, price not (Pp iii +61 ; paperback, price not
stated.) Bath: University of Bath: Centre for the Analysis of Social Policy, Centre for the Analysis of Social

EURO Reports and Studies 107. "Men tal Health Services in Southern Countries of the European Region." Report on a WHO Meeting. World Health

Organisation. (Pp 46; Sw frs 6 paperback.) Copenhagen: World Healt Organisation Regional Office fo Europe, 1988. ISBN 92-890-1273-0.

Frameworks for Change: a Review of Regional Health Authorities' Strategies
for Promoting Community-Based Serfor Promoting Community-Based Ser-
vices to People with Learning Difficulvices to People with Learning Difficulties. Independent Development Coun-
cil for People with Mental Handicap. cil for People with Mental Handicap.
(Pp 64; $£ 3$ including postage, paper(Pp 64; $£ 3$ including postage, paper-
back.) 1988. Available from IDC, back.) 1988. Available from IDC,
Publications Department, 126 Albert Publications Department, 126
Street, London NW1 7NF.

The Health Conspiracy. J Collier. (Pp xiv $+175 ; £ 4.95$ paperback.) London: Century Hutchinson, 1989. ISBN 0-7126-1859-7.

The David Hume Institute: Hume Paper No 9. "How Should Health Services Be Financed? A Patient's View." Report on a Conference, June 1988. A Massie. (Pp 52; 26.95 paperback.) Aberdeen: Aberdeen University Press, 1988. ISBN 0-08-036585-X.

World Health Organisation Technical Report Series 769. "Learning Together to Work Together for Health." Re 